\title{
Catalytic Abatement of VOCs: Aerobic Combustion of Methane or Ethane over Alumina-Supported Metal Oxides Recovered from Spent Catalysts
}

\author{
Saad Tahir ${ }^{1} \&$ Hallo Askari ${ }^{2}$ \\ ${ }^{1}$ Richmond University, The American International University in London, London, United Kingdom \\ ${ }^{2}$ Environmental Protection and Improvement Board, Manti Kawa, Erbil, Kurdistan, Iraq \\ Correspondence: Saad Tahir, Richmond University, The American International University in London, Queens \\ Road, Richmond upon Thames, London TW10 6JP, United Kingdom. E-mail: tahirs@richmond.ac.uk
}

\author{
Received: March 13, 2020 \\ Accepted: April 8, $2020 \quad$ Online Published: May 5, 2020 \\ doi:10.5539/enrr.v10n2p33 \\ URL: https://doi.org/10.5539/enrr.v10n2p33
}

\begin{abstract}
$\gamma-\mathrm{Al}_{2} \mathrm{O}_{3}$ supported $\mathrm{Cu}, \mathrm{Cu}-\mathrm{Zn}$ and $\mathrm{Cu}-\mathrm{Ni}-\mathrm{Fe}-\mathrm{Zn}$ oxide catalysts were prepared using leachate transition metal nitrate and sulfate aqueous solutions from commercial spent catalysts. A bench-scale rig was used to investigate the combustion activity of these catalysts toward methane or ethane in the air stream (1000 ppmv) at a space velocity of $20,000 \mathrm{~h}^{-1}$. The $\mathrm{Cu}-\mathrm{Ni}-\mathrm{Fe}-\mathrm{Zn}$ oxides $/ \gamma-\mathrm{Al}_{2} \mathrm{O}_{3}$ catalyst proved to be the most active catalyst for the combustion of methane in the temperature range $290-575^{\circ} \mathrm{C}$ and of ethane in the lower temperature range of $275-525^{\circ} \mathrm{C}$ as compared to $\mathrm{Cu}$ and $\mathrm{Cu}-\mathrm{Zn}$ oxide loaded catalysts. X-ray powder diffractograms indicated that the metal oxide species were highly dispersed or amorphous on the alumina surface in all the catalysts except for the detection of a minority phase of monoclinic $\mathrm{CuO}$ on the $\mathrm{Cu}$-containing mono-metallic catalysts. The co-existence of $\mathrm{ZnO}$ in the $\mathrm{CuO}$ catalysts suppresses the activity of the copper oxide species and, therefore, the conversion of methane or ethane was reduced. The present research endeavor provides proof-of-concept that relatively inexpensive metal oxide-based heterogeneous catalysts for VOCs abatement can be recovered from spent catalysts. Hence, environmental and health threats of improper handling of VOCs or spent catalysts may be alleviated.
\end{abstract}

Keywords: Recycled Metal Oxide Catalysts, Spent Catalysts, Catalytic Combustion of Methane and Ethane, X-Ray Powder Diffractometry, Supported Cu Oxide Catalysts, Supported Cu-Ni-Fe-Zn Oxide Catalyst

\section{Introduction}

Volatile organic compounds (VOCs) are recognized as a major threat both to the environment and human health (Spivey, 1987; Liotta, 2010). VOCs include hydrocarbons (HCs) and hetero-atom containing organic compounds. Catalytic combustion (i.e., total oxidation) has become a favorable alternative to thermal oxidation as an effective method for the elimination of the usually low-concentrated VOCs in air streams. The key advantages of using catalytic combustion, compared with other decontamination technologies, include: (i) high efficiency at low pollutant concentrations, (ii) low energy consumption, and (iii) low formation rates of secondary pollutants, e.g. noxious nitrogen oxide (Morales et al., 2008).

Unlike condensation and adsorption technologies, catalytic combustion does not reform HC pollutants but oxidizes them completely into $\mathrm{CO}_{2}$ and $\mathrm{H}_{2} \mathrm{O}$, which are environmentally much less harmful materials. Supported noble metals (Diehl et al., 2010; [5] Kim \& Ahn, 2009; Shim et al., 2008), metal oxides (Todorova et al., 2010; Kim, 2002; Spivey \& Butt, 1992; Kim \& Shim, 2010) and mixed metal oxides (Kim \& Ihm, 2001; Mu et al., 2008; Jirátová et al., 2009) have been widely employed for the catalytic combustion of VOCs. Even though transition metal oxides are less active catalysts than noble metals, they are cost-effective, environmentally friendly, and more resistant to poisoning and sintering than the noble metals (Morales et al., 2008; Spivey \& Butt, 1992; Vu et al., 2008). Recently, Kamal et al. (2016) and Zhang et al. (2016) reviewed the elimination of VOCs using different catalytic oxidation processes with noble metal and metal oxide catalysts.

It is important to reduce methane and ethane emissions into the atmosphere; therefore, the present investigation was designed to focus on the combustion of methane and ethane in air. Although methane is the least reactive of the hydrocarbons, and therefore the most difficult to oxidize, the legislation on its emission still requires the 
removal of trace amounts of it. $\mathrm{SnO}_{2}$ has shown some activity by itself in the combustion of methane (Cullis \& Willatt, 1983). Xiao et al. (2001) reported that cobalt oxides supported on $\mathrm{ZrO}_{2}$ have higher oxidation activity than not only cobalt oxides supported on $\mathrm{TiO}_{2}, \mathrm{Al}_{2} \mathrm{O}_{3}$ or $\mathrm{MgO}$ catalysts, but also than the bulk $\mathrm{Co}_{3} \mathrm{O}_{4}$. Li et al. (2009) observed that a mixed Co-Mn oxide catalyst with a $\mathrm{Co} / \mathrm{Mn}$ molar ratio of 5 , prepared by the co-precipitation method, facilitated $90 \%$ oxidation of methane at $320^{\circ} \mathrm{C}$. Also, Chen et al. (2013) prepared Co-Cr mixed oxide catalyst with a $\mathrm{Co} / \mathrm{Cr}$ molar ratio of 0.5 , by co-precipitation, and found it to accomplish $90 \%$ oxidation at $464^{\circ} \mathrm{C}$.

With respect to the catalytic combustion of ethane, several studies have been performed on using supported Pt and Pd catalysts (Noordally et al., 1993; Tahir \& koh, 1996). Kucherov et al. (1996) observed that a Cu-ZSM-5 catalyst facilitated the oxidation of ethane in the air at $500-650{ }^{\circ} \mathrm{C} . \mathrm{MnO}_{2}$ (4 wt. $\left.\%-\mathrm{Mn}\right) / \mathrm{SnO}_{2}$ catalyst prepared by impregnation showed very high activity in the total oxidation of 0.2 vol.\% ethane in the air (Tahir \& Koh, 1997). Other investigations on ethane have been carried out using different transition metal oxides mounted on $\mathrm{SnO}_{2}$. Supported metal oxide catalysts, such as $\mathrm{Mn}, \mathrm{Co}, \mathrm{Cu}, \mathrm{Ce}$, and $\mathrm{Ni}$ were studied and showed that $\mathrm{Mn}$ and $\mathrm{Co}$ oxides were the most active catalysts in the combustion of ethane at $420-440^{\circ} \mathrm{C}$ (Tahir \& Koh, 1997). The total oxidation of ethane over $\mathrm{Pd} / \alpha-\mathrm{Al}_{2} \mathrm{O}_{3}$ in an oxygen-rich atmosphere showed more activity after reduction with hydrogen at $300^{\circ} \mathrm{C}$, and the rate of reaction was found to depend on the total amount of Pd (Anderson et al., 1961).

There is a constant need in the field of VOCs abatement for developing cost-effective catalysts of high activity and durability. Therefore, using transition metal ions recovered from spent commercial catalysts, which were used in chemically-related applications, to produce metal oxide-based active catalysts for VOCs combustion is worth attempting for the following environmental advantages: (i) VOCs abatement in air, and (ii) avoiding improper disposal of the spent catalysts.

Therefore, the present investigation was designed to undertake the following studies. Recovery of transition metal ions $\left(\mathrm{Cu}, \mathrm{Ni}, \mathrm{Fe}\right.$, and $\mathrm{Zn}$ ) from commercial spent catalysts via acid $\left(\mathrm{HNO}_{3}\right.$ or $\left.\mathrm{H}_{2} \mathrm{SO}_{4}\right)$ based traditional extraction method. Preparation of $\gamma-\mathrm{Al}_{2} \mathrm{O}_{3}$-supported oxides via (i) impregnation of the support with the nitrate or sulfate solutions of the recovered metal ions, and (ii) subsequent calcination at 450 or $650^{\circ} \mathrm{C}$. Analogous sets of the catalysts were similarly prepared, but using impregnating solutions of commercial metal nitrates or sulfates, and handled as reference catalysts for control purposes. The prepared catalysts were characterized using atomic absorption spectroscopy for the determination of their transition metal contents, X-ray powder diffractometry for the elucidation of their crystalline phase composition, and (iii) $\mathrm{N}_{2}$ sorptiometry for the determination of their BET-surface areas. Subsequently, the $\mathrm{CH}_{4}$ and $\mathrm{C}_{2} \mathrm{H}_{6}$ combustion activity of the catalysts, whether the recycled or the reference catalysts, was measured employing a fixed-bed continuous flow reactor and gas chromatography.

\section{Experimental}

\subsection{Catalysts Preparation}

The used $\gamma-\mathrm{Al}_{2} \mathrm{O}_{3}$ support was obtained from UOP (UK). It was grounded to small particles of less than $0.5 \mathrm{~mm}$ in size before use, and found to assume a specific surface area of $120 \mathrm{~m}^{2} \mathrm{~g}^{-1}$. The impregnating solutions of $\mathrm{Cu}, \mathrm{Cu}-\mathrm{Zn}$ and $\mathrm{Cu}-\mathrm{Ni}-\mathrm{Fe}-\mathrm{Zn}$ metal ions were obtained by leaching spent catalysts with nitric or sulfuric acids, adopting a traditional acid extraction technique (Askari, 2007; Li et al., 2007; Arslan \& Arslan, 2002). Typically, a 2-g portion of pulverized spent catalyst (supplied by Amlon Metal Limited (UK)) was mixed with $100 \mathrm{~cm}^{3}$ of the leach acid solution $\left(69 \% \mathrm{HNO}_{3}\right.$ or $98 \% \mathrm{H}_{2} \mathrm{SO}_{4}(\mathrm{w} / \mathrm{w})$ at fixed concentration of 3 mole $\left.\mathrm{dm}^{-3}\right)$ in a $0.5 \mathrm{dm}^{3}$ flange flask. Then, the flask was placed on a hot plate for $1-2$ hours at $50-75^{\circ} \mathrm{C}$. The mixture was stirred using a magnetic stirrer. The leachate obtained was filtered and transferred to a $200 \mathrm{~cm}^{3}$ volumetric flask and made up to the mark with deionised water (final $\mathrm{pH} \leq 4$ ). On the other hand, $\mathrm{Cu}, \mathrm{Ni}, \mathrm{Fe}$ and $\mathrm{Zn}$ nitrate and sulfate precursor compounds used to prepare reference catalysts (for control purposes) were 99.8\%-pure Aldrich products. Their impregnating solutions were prepared in deionised water.

Supported $\mathrm{Cu}, \mathrm{Cu}-\mathrm{Zn}$ and $\mathrm{Cu}-\mathrm{Ni}-\mathrm{Fe}-\mathrm{Zn}$ oxides catalysts were prepared by impregnating the $\gamma-\mathrm{Al}_{2} \mathrm{O}_{3}$ support particles with the metal ions aqueous solution $\left(10 \mathrm{~mL} / \mathrm{g}-\mathrm{Al}_{2} \mathrm{O}_{3}\right)$, whether the leachate or the commercial solution was used. The resultant suspension was stirred well, and the excess water removed/evaporated using a rotary evaporator. The solid product was dried further in air at $120^{\circ} \mathrm{C}$ for $24 \mathrm{~h}$ and, then, calcined in air at $450^{\circ} \mathrm{C}$ (for the nitrate solution) or $650^{\circ} \mathrm{C}$ (for the sulfate solution) for $5 \mathrm{~h}$. When heated in air, $\mathrm{CuSO}_{4}$ undergoes phase transitions, and, according to the literature (Arslan \& Arslan, 2002; Abdel Basir \& Rabah, 1999), converts into $\mathrm{CuO}$ at $650^{\circ} \mathrm{C}$. For simplicity, each of the resulting catalysts is discerned below by a code number and a designation made-up of the chemical symbol(s) and amount(s) of the transition metal ions loaded, and the nature of the impregnating solution used. All recycled and reference catalysts prepared and examined in the present investigation are identified in Table 1. 
Table 1. Catalyst code, elemental composition, impregnating solution used, and type

\begin{tabular}{llll}
\hline Code $^{\mathbf{a}}$ & Composition $^{\mathbf{b}}$ & Impregnating solution $^{\mathbf{c}}$ & Type \\
\hline Cat-1 & $\mathrm{Cu} 2.2 \mathrm{Zn} 4.6$ & $\mathrm{LNS}$ & Recycled \\
Cat-2 & $\mathrm{Cu} 2.2 \mathrm{Zn} 4.8$ & $\mathrm{LSS}$ & Recycled \\
Cat-3 & $\mathrm{Cu} 2.2 \mathrm{Zn} 0.03$ & $\mathrm{LSS}$ & Recycled \\
Cat-4 & $\mathrm{Cu} 2.2$ & $\mathrm{RNS}$ & Reference \\
Cat-5 & $\mathrm{Cu} 5.0$ & $\mathrm{RNS}$ & Reference \\
Cat-6 & $\mathrm{Zn} 4.6$ & $\mathrm{RNS}$ & Reference \\
Cat-7 & $\mathrm{Cu} 0.11 \mathrm{Ni} 1.9 \mathrm{Fe} 0.3 \mathrm{Zn} 0.14$ & $\mathrm{LNS}$ & Recycled \\
Cat-8 & $\mathrm{Cu} 2.2 \mathrm{Zn} 4.6$ & $\mathrm{RNS}$ & Reference \\
Cat-9 & $\mathrm{Cu} 2.2 \mathrm{Zn} 4.8$ & $\mathrm{RSS}$ & Reference \\
Cat-10 & $\mathrm{Cu} 0.11 \mathrm{Ni} 1.9 \mathrm{Fe} 0.3 \mathrm{Zn} 0.14$ & $\mathrm{RNS}$ & Reference \\
Cat-0 & $\gamma-\mathrm{Al}_{2} \mathrm{O}_{3}$ & - & Support \\
\hline
\end{tabular}

${ }^{a}$ Catalysts 4-6 are mono-metallic; catalysts $1-3,8$ and 9 are bi-metallic; whereas catalysts 7 and 10 are quatro-metallic.

${ }^{\mathrm{b}}$ Arabic numerals indicate amount (wt $\left.\%\right)$ of the preceding metal ion

${ }^{\mathrm{c}} \mathrm{LNS}=$ impregnated with leached metal nitrate solution;

LSS = impregnated with leached metal sulfate solution;

RNS = impregnated with commercial metal nitrate solution;

RSS $=$ impregnated with commercial metal sulfate solution .

\subsection{Catalysts Chacterization}

Atomic absorption spectroscopy was carried out with a model Perkin-Elmer 2380 spectrometer. The Brunner-Emmett-Teller specific (BET) surface areas of all catalyst samples were determined via $\mathrm{N}_{2}$ sorptiometry at liquid nitrogen temperature $\left(-196^{\circ} \mathrm{C}\right)$ using a Micromeritics ASAP 2020 analyzer. Prior to Nitrogen sorption analysis, all the samples were degassed under vacuum $\left(5 \times 10^{-3} \mathrm{mmHg}\right)$ for $6 \mathrm{~h}$ at $250^{\circ} \mathrm{C}$. X-ray powder diffractometry (XRD) was conducted employing a Philips PW1710 diffractomer equipped with Ni-filtered $\mathrm{CuK}_{\alpha}$ radiation $(\lambda=0.15403 \mathrm{~nm})$ operated at $40 \mathrm{keV}$ and $30 \mathrm{~mA}$. Test catalysts were investigated in the $2 \theta$ range of $4-100^{\circ}$ at a scanning rate of $1.1 \%$ h. Diffraction patterns thus obtained were matched with standard diffraction data (International Center for Diffraction data, 2018) for crystalline phase composition identification.

\subsection{Catalytic Activity}

Methane and ethane catalytic combustion experiments were carried out in a fixed-bed continuous flow quartz reactor (i.d. $=1.5 \mathrm{~cm}$ ) operating under atmospheric pressure. The quartz reactor in the activity rig contained an inner quartz cup to hold the catalyst, which was housed in a tubular furnace. In each experiment, a 2-mL portion of catalyst was placed in the reactor supported by quartz wool. Thermocouples monitored the inlet and outlet temperatures, measuring the gas temperature. An on-line Perkin-Elmer F-11 gas chromatograph with a flame ionisation detector (FID) was used to monitor the total unburned hydrocarbon in the exit gas. In all activity tests performed, $1000 \mathrm{ppmv}$ methane (or ethane) in air was fed into the reactor at a gas hourly space velocity of 20,000 $\mathrm{h}^{-1}$ and the temperature range during the test was from 100 to $600^{\circ} \mathrm{C}$, with $5{ }^{\circ} \mathrm{C} / \mathrm{min}$ as ramping rate. The combustion products were $\mathrm{CO}_{2}$ and $\mathrm{H}_{2} \mathrm{O}$, and other by-products were detectable under the experimental conditions applied. A blank test was conducted without a catalyst to examine the effect of the quartz wool and the quartz reactor and to confirm that no homogeneous reaction occurred below $600^{\circ} \mathrm{C}$. The catalytic results obtained for methane (or ethane) as a function of the reaction temperature, collected after ensuring the steady state condition at a given temperature, resulted in S-shaped curves. The methane (or ethane) conversion $\%$ was calculated based on the hydrocarbon consumption:

$$
\text { Conversio }(0)=\frac{C_{i}-C_{o}}{C_{i}} \times 100
$$

Where, $C_{i}=$ inlet concentration of the VOC in the feed

$C_{o}=$ outlet concentration of the $\mathrm{VOC}$ in the effluent. 


\section{Results and Discussion}

\subsection{Catalysts Elemental and Phase Compositions}

Table 1, reveals that the test catalysts may be sub-grouped as mono-metallic (Cat-4 to Cat-6), bi-metallic (Cat-1 to Cat-3, and Cat-8 and Cat-9), and quatro-metallic (Cat-7 and Cat-10) catalysts. Table 1 also reveals that the mono-metallic catalysts are reference catalysts, in which Cat- 4 and Cat- 5 contain different amounts of $\mathrm{Cu}$ ions, and Cat- 6 contains $\mathrm{Zn}$ ions. However, the bi-metallic catalysts are identified to be either recycled (Cat- 1 to Cat-3) or reference (Cat- 8 and Cat-9) catalysts. In all the bi-metallic catalysts, the metallic constitution is made up of $2.2 \% \mathrm{Cu}$ and $4.6-4.8 \% \mathrm{Zn}$ ions, except for Cat-3 which has the same amount of $\mathrm{Cu}$ but only a scarce amount of $\mathrm{Zn}$ $(0.03 \%)$ and the quarto-metallic Cat-7 and Cat- 10 are respectively recycled and reference catalysts each containing $0.11 \% \mathrm{Cu}, 1.9 \% \mathrm{Ni}, 0.3 \% \mathrm{Fe}$ and $0.14 \% \mathrm{Zn}$. Table 1 reveals, moreover, that the metallic constitution of Cat 3 to Cat-5 is Cu-majored, and that of Cat-1, Cat-2, Cat-6, Cat-8 and Cat-9 is Zn-majored, whereas that of Cat-7 and Cat-10 is Ni-majored. It is worth noting, that the pure support $\left(\gamma-\mathrm{Al}_{2} \mathrm{O}_{3}\right)$ is coded Cat- 0 (Table 1).

The corresponding XRD results (Figure 1 and Table 2) indicate that except for Cat-1 and Cat-2, the bulk crystalline phase composition is either dominated (Cat-3) or majored (Cat- 6 to Cat-10) by the $\gamma-\mathrm{Al}_{2} \mathrm{O}_{3}$ support. The minor crystalline phases identified are $\alpha-\mathrm{Al}_{2} \mathrm{O}_{3}$ in Cat-3 and Cat- 6 to Cat-10, and $\alpha-\mathrm{Al}_{2} \mathrm{O}_{3}$ and m-CuO in both Cat- 4 and Cat-5. Thus, the XRD results may suggest that the $\gamma-\mathrm{Al}_{2} \mathrm{O}_{3}$ support can strongly disperse up to the highest loading levels used of $\mathrm{Zn}, \mathrm{Ni}$ and $\mathrm{Fe}$, but cannot do likewise for $\geq 2.2 \% \mathrm{Cu}$ in its mono-metallic catalysts (Cat- 4 and Cat-5). In the meantime, the $\gamma-\mathrm{Al}_{2} \mathrm{O}_{3}$ support is shown (Figure 1 and Table 2) to suffer a minor polymorphic transition (in Cat-3 to Cat-10) to the thermodynamically favorable $\alpha-\mathrm{Al}_{2} \mathrm{O}_{3}$ phase (Wefers \& Misra, 1987). The temperature regime $\left(\leq 650^{\circ} \mathrm{C}\right)$ at which this polymorphic transition commenced to occur is much less than that $\left(\geq 950^{\circ} \mathrm{C}\right)$ reported for the transition involving pure $\gamma-\mathrm{Al}_{2} \mathrm{O}_{3}$ (Wefers \& Misra, 1987). This may help presuming that the minor $\gamma$-to- $\alpha-\mathrm{Al}_{2} \mathrm{O}_{3}$ phase transition observed is, somehow, metal ion-assisted.

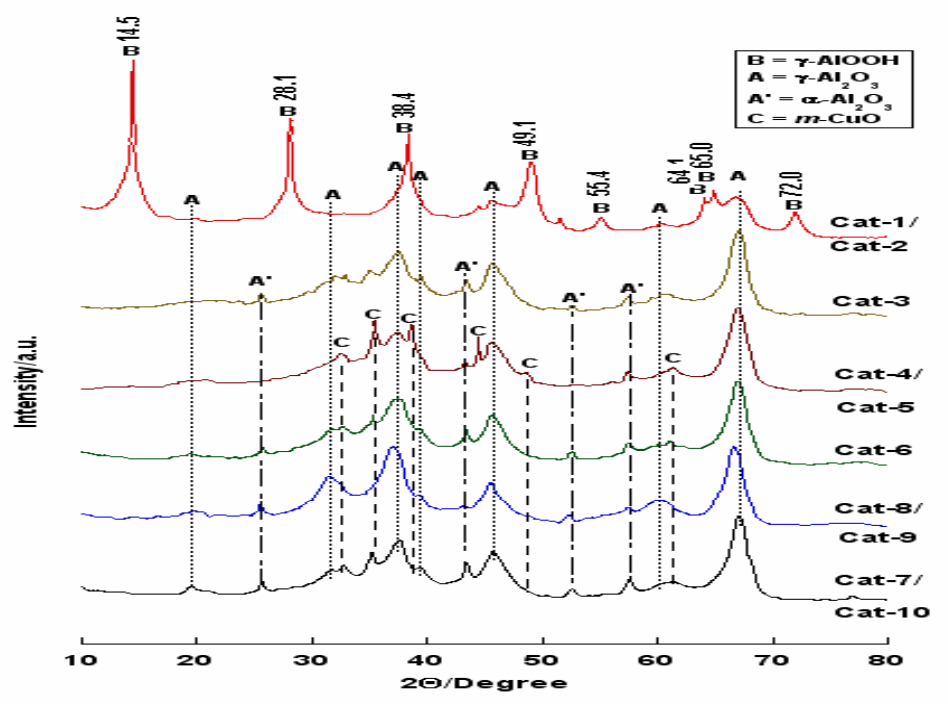

Figure 1. X-ray powder diffractograms obtained for the recycled and reference catalysts

On the other hand, the bi-metallic Cat-1 and Cat-2 exhibit uniquely similar XRD diffractograms (Figure 1) dominated by diffraction peaks $\left(2 \theta=14.5,28.1,38.4,49.1,55.4,64.1,65.0\right.$ and $\left.72.0^{\circ}\right)$ matching those reported (International Center for Diffraction data, 2018; Wefers \& Misra, 1987) for the layer-structured crystalline boehmite $(\gamma-\mathrm{AlO}(\mathrm{OH})$. According to data reported elsewhere (Wefers \& Misra, 1987), this experimental result may mean that the initial $\gamma-\mathrm{Al}_{2} \mathrm{O}_{3}$ must have dissolved, at least a good proportion of it, in the strongly acidic medium $(\mathrm{pH} \leq 4)$ furnished during the impregnation process of $\mathrm{Cu}$ and $\mathrm{Zn}$ ions. The heat treatment imposed by the process must have provided an encouraging hydrothermal condition for the precipitation of $\gamma$ - $\mathrm{AlO}(\mathrm{OH})$ (Wefers \& Misra, 1987). The fact that the d-spacing $(0.599 \mathrm{~nm})$ corresponding to the strongest diffraction peak $\left(2 \theta=14.5^{\circ}\right)$ is slightly less than that $(0.615 \mathrm{~nm})$ reported for pure $\gamma-\mathrm{AlO}(\mathrm{OH})$ (Wefers \& Misra, 1987) may view more closely stacked layers in the boehmite formed in the present catalysts. Intercalary inserted metal ions of the catalysts may explain the closer stacking of atomic layers in the $\gamma$ - $\mathrm{AlO}(\mathrm{OH})$ structure. It is worth noting, however, that the diffractogram still declares the presence of a minor proportion of $\gamma-\mathrm{Al}_{2} \mathrm{O}_{3}$ in the catalysts (Cat-1 and Cat-2). This 
may reflect that the $\gamma-\mathrm{Al}_{2} \mathrm{O}_{3}$ to $\gamma-\mathrm{AlO}(\mathrm{OH})$ conversion process is kinetically controlled under the hydrothermal condition furnished during the impregnation process. It may appear surprising that the also recycled bi-metallic Cat-3 (Table 1) has given rise to a diffraction pattern completely void of the diagnostic peaks of $\gamma-\mathrm{AlO}(\mathrm{OH})$, though a similarly strong acidic medium was furnished. The difference between the metallic constitutions of Cat-3 and the catalysts Cat- 1 and -2 lies in its much smaller content of $\mathrm{Zn}$ ions ( 0.03 vs. 4.8\%), which may supposedly emphasize the importance of intercalation of $\mathrm{Zn}$ ions (rather than $\mathrm{Cu}$ ions) to the stabilization of the layer structure of $\gamma-\mathrm{AlO}(\mathrm{OH})$, though $\mathrm{Cu}^{2+}$ and $\mathrm{Zn}^{2+}$ are of comparable ionic radii, namely 73 vs. 74 pm (Aylward \& Findlay, 1994).

Table 2. XRD-determined crystalline phase composition of the recycled and reference catalysts

\begin{tabular}{llll}
\hline Catalyst & Phase composition & Abundance & JCPDS $^{\mathbf{a}}$ \\
\hline \multirow{2}{*}{ Cat-1/-2 } & $\gamma-\mathrm{AlO}(\mathrm{OH})^{\mathrm{b}}$ & Major & $83-2384$ \\
& $\gamma-\mathrm{Al}_{2} \mathrm{O}_{3}$ & Minor & $29-0063$ \\
Cat-3 & $\gamma-\mathrm{Al}_{2} \mathrm{O}_{3}$ & Dominant & $29-0063$ \\
& $\alpha-\mathrm{Al}_{2} \mathrm{O}_{3}$ & Trace & $85-1337$ \\
\multirow{2}{*}{ Cat-4/-5 } & $\gamma-\mathrm{Al}_{2} \mathrm{O}_{3}$ & Major & $29-0063$ \\
& $\mathrm{~m}-\mathrm{CuO}^{\mathbf{c}}$ & Minor & $48-1548$ \\
\multirow{2}{*}{ Cat-6/-8/-9 } & $\alpha-\mathrm{Al}_{2} \mathrm{O}_{3}$ & Trace & $85-1337$ \\
& $\gamma-\mathrm{Al}_{2} \mathrm{O}_{3}$ & Dominant & $29-0063$ \\
Cat-7/-10 & $\alpha-\mathrm{Al}_{2} \mathrm{O}_{3}$ & Trace & $85-1337$ \\
& $\gamma-\mathrm{Al}_{2} \mathrm{O}_{3}$ & Major & $29-0063$ \\
\hline
\end{tabular}

${ }^{\mathrm{a}}$ JCPDS card number (International Center for Diffraction data, 2018); ${ }^{\mathrm{b}}$ Boehmite; ${ }^{\mathrm{c}} \mathrm{m}=$ monoclinic.

\subsection{The Catalytic Activity}

The activity of the test catalysts in the combustion (total oxidation) of methane (or ethane) was assessed with 1000 ppmv in air as function of the reaction temperature $\left(275-600^{\circ} \mathrm{C}\right)$. Experimental data were collected after ensuring the steady state condition at each reaction temperature. Irrespective of the catalyst tested, no conversion of methane (or ethane) species was detectable at $<275^{\circ} \mathrm{C}$; it commenced and increased with the reaction temperature $\left(\geq 275^{\circ} \mathrm{C}\right)$. On the pure $\gamma-\mathrm{Al}_{2} \mathrm{O}_{3}$ (Cat- 0 ), no conversion was observed up to $500^{\circ} \mathrm{C}$, and only a negligible conversion $(\leq 2 \%)$ was observed at $600^{\circ} \mathrm{C}$. The light-off temperature $\left(\mathrm{T}_{10}\right)$ is the minimum temperature at which noticeable conversion occurs, while $\mathrm{T}_{50}$ and $\mathrm{T}_{90}$ are the temperatures at which $50 \%$ and $90 \%$ conversion were accomplished. These were readily determined from the conversion-temperature plots compared in Figures 2 and 3 for the combustion of methane or ethane, respectively, and set out, alongside the catalyst specific surface area in Table 3. These results show that on a given catalyst the $T_{10}$ of ethane assumes a lower value than that of methane, thus revealing, expectedly, the more facile oxidation of the former than the later VOC.

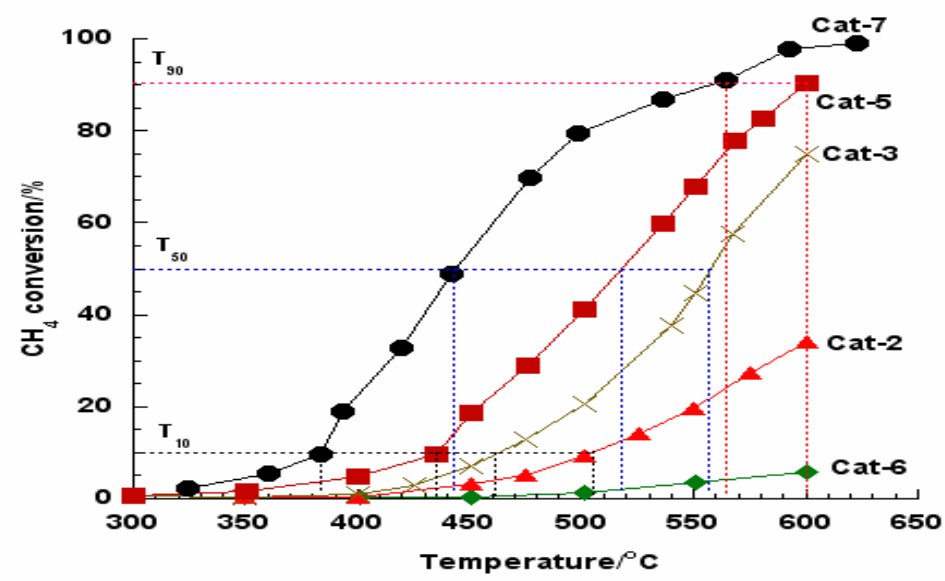

Figure 2. Plots of methane conversion (\%) as a function of reaction temperature over the catalysts indicated 
Considering the relative performances of the mono-metallic catalysts, the Cu-containing catalysts (Cat-4 and -5) show much higher activity in the oxidation of methane (or ethane) than the Zn-containing Cat-6. In fact, Cat-6 is shown to be the least active relative to all the catalysts tested. The fact that, the mono-metallic catalysts were found to assume similarly high specific surface areas $\left(\mathrm{S}_{\mathrm{BET}}=104-107 \mathrm{~m}^{2} / \mathrm{g}\right.$, Table 3$)$ and that the $\mathrm{Zn}$ content $(4.6 \%)$ is shown not to segregate into XRD-detectable separate phases (Table 2), may help revealing that $\mathrm{Cu}$ sites are much more active oxidation centers for methane (or ethane) than $\mathrm{Zn}$ sites. There is a consensus that the catalytic oxidation function is more facilitated on strongly basic sites and/or redox sites exposed on the catalysts (Hussein et al., 1991). The former sites ought to be capable of oxidative dehydrogenation (like in the dehydrogenation of alcohols (Hussein et al., 1991)), whereas the latter capable of generating surface electron mobility (like in coupled redox metal sites (Standard electrode potential, 2018). Reported redox potential of $\mathrm{Cu}^{2+} / \mathrm{Cu}^{+}(=+0.15 \mathrm{~V})$ is much higher than that $(=-1.199 \mathrm{~V})$ of $\mathrm{Zn}^{2+} / \mathrm{Zn}^{0}$, a fact that accounts for a much more facile electron mobilization in the $\mathrm{Cu}$ redox system than in the $\mathrm{Zn}$ redox system (Standard electrode potential, 2018).

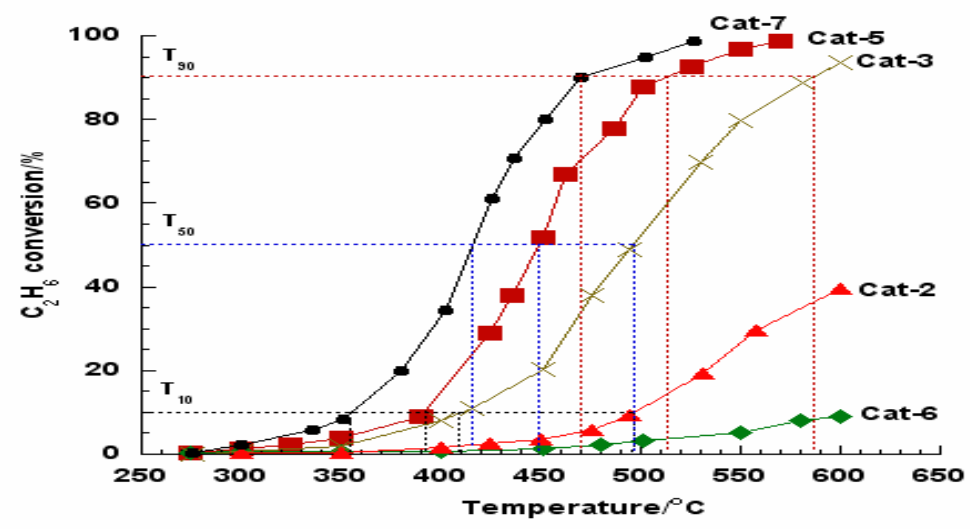

Figure 3. Plots of ethane conversion (\%) as a function of reaction temperature over the catalysts indicated

Table 3. Catalyst BET-surface area, and the thereon determined combustion temperatures of methane or ethane in air at $10 \%, 50 \%$ and $90 \%$ conversion efficiencies

\begin{tabular}{llllllll}
\hline & & \multicolumn{3}{c}{ Combustion temperature of methane } & \multicolumn{3}{c}{ Combustion temperature of ethane } \\
Catalyst & \multirow{2}{*}{$\mathbf{S}_{\mathbf{B E T}} / \mathbf{m}^{2} \mathbf{g}^{-1}$} & $\mathbf{T}_{\mathbf{1 0}}$ & $\mathbf{T}_{\mathbf{5 0}}$ & $\mathbf{T}_{\mathbf{9 0}}$ & $\mathbf{T}_{\mathbf{1 0}}$ & $\mathbf{T}_{\mathbf{5 0}}$ & $\mathbf{T}_{\mathbf{9 0}}$ \\
& & ${ }^{\circ} \mathbf{C}$ & ${ }^{\circ} \mathbf{C}$ & ${ }^{\circ} \mathbf{C}$ & ${ }^{\circ} \mathbf{C}$ & ${ }^{\circ} \mathbf{C}$ & ${ }^{\circ} \mathbf{C}$ \\
\hline Cat-0 $^{\text {a }}$ & 118 & n.d & n.d & n.d & n.d & n.d & n.d \\
Cat-1 & 107 & $\mathbf{4 7 7}$ & n.d & n.d & $\mathbf{4 6 0}$ & $\mathbf{5 8 8}$ & n.d \\
Cat-2 & 97 & $\mathbf{5 0 3}$ & n.d & n.d & $\mathbf{4 9 6}$ & n.d & n.d \\
Cat-3 & 95 & $\mathbf{4 6 1}$ & $\mathbf{5 5 8}$ & n.d & $\mathbf{4 1 0}$ & $\mathbf{4 9 6}$ & $\mathbf{5 8 8}$ \\
Cat-4 & 104 & $\mathbf{4 3 4}$ & $\mathbf{5 3 1}$ & $\mathbf{6 0 0}$ & $\mathbf{3 6 5}$ & $\mathbf{4 4 0}$ & $\mathbf{5 1 3}$ \\
Cat-5 & 105 & $\mathbf{4 3 5}$ & $\mathbf{5 1 8}$ & $\mathbf{6 0 0}$ & $\mathbf{3 9 2}$ & $\mathbf{4 5 0}$ & $\mathbf{5 1 2}$ \\
Cat-6 & 107 & n.d & n.d & n.d & n.d & n.d & n.d \\
Cat-7 & 105 & $\mathbf{3 8 3}$ & $\mathbf{4 4 3}$ & $\mathbf{5 6 5}$ & $\mathbf{3 5 5}$ & $\mathbf{4 1 5}$ & $\mathbf{4 7 0}$ \\
\hline
\end{tabular}

${ }^{\text {aP }}$ Pure $\gamma-\mathrm{Al}_{2} \mathrm{O}_{3}$ is coded as Cat $-0 ;{ }^{b}$ n.d $=$ Not determinable

Accordingly, one may explain the much higher oxidation activity of methane (or ethane) observed on Cat- 4 and -5 than Cat- 6 by the easiness with which the oxidation state of $\mathrm{Cu}$ is shuttled between the divalent and mono-valent states and the higher electron mobility thereby facilitated.

The above discussion may still be extended to the $\mathrm{Cu}-\mathrm{Zn}$ bimetallic Cat-3, which may be considered a quasi-mono-metallic $\mathrm{Cu}$-containing (2.2\%) catalyst but with a scarce amount of $\mathrm{Zn}(0.03 \%)$. It is obvious from Figures 2 and 3, and Table 3, that the co-existence of such a minute amount of $\mathrm{Zn}$ was sufficient to render Cat-3 detectably less active than the $\mathrm{Cu}$-containing mono-metallic Cat- $4(2.2 \% \mathrm{Cu})$. This may presume that the dispersed $\mathrm{Zn}$ atoms might have covered up parts of the exposed $\mathrm{Cu}$ redox sites. A weaker activity was observed for the reference $\mathrm{Cu}-\mathrm{Zn}$ bimetallic Cat-8 and -9 , which may, thus, be attributed to their higher contents of $\mathrm{Zn}(2.2 \%)$. Whereas the still weaker activity of the recycled $\mathrm{Cu}-\mathrm{Zn}$ bimetallic $\mathrm{Ca}-1$ and -2 may well be ascribed to the radical 
change happened in their phase compositions accompanying the support $\left(\gamma-\mathrm{Al}_{2} \mathrm{O}_{3}\right)$ transformation into the boehmite $(\gamma-\mathrm{AlO}(\mathrm{OH}))$ phase (Table 2$)$ as assisted by the inevitably strong acidity $(\mathrm{pH} \leq 4)$ of the recovered impregnating solution. Such a radical change might enclose coexisting metal ions (viz., $\mathrm{Cu}$ and $\mathrm{Zn}$ ) leaving behind only low proportions of them exposed on the surface. It is worth noting, that the non-occurrence of such $\gamma-\mathrm{Al}_{2} \mathrm{O}_{3}$ to $\gamma-\mathrm{AlO}(\mathrm{OH})$ transformation in the reference Cat-8/-9 was due, most likely, to the failure of their prepared impregnating solution $(\mathrm{pH}=5.5)$ to furnish the strong acidity $(\mathrm{pH} \leq 4)$ capable of dissolving the $\gamma-\mathrm{Al}_{2} \mathrm{O}_{3}$ support (Table 2). A role for the accompanying loss on the surface area from $118\left(\gamma-\mathrm{Al}_{2} \mathrm{O}_{3}\right)$ down to 107 (Cat-1) and further to $97 \mathrm{~m}^{2} / \mathrm{g}$ (Cat-2) cannot be excluded with certainty.

The quatro-metallic Cat- 7 and Cat-10 are similarly majored by $1.9 \%$-Ni and minored by $0.11 \% \mathrm{Cu}, 0.3 \% \mathrm{Fe}$ and $0.14 \% \mathrm{Zn}$ (Table 1), but Cat-7 is recycled and Cat-10 is a reference catalyst. Based on the XRD results (Table 2), the phase composition of both catalysts is also similarly majored by $\gamma-\mathrm{Al}_{2} \mathrm{O}_{3}$ and minored by $\alpha-\mathrm{Al}_{2} \mathrm{O}_{3}$ with no detectable indication for segregated transition metal oxide phases (Figure 1). Hence, it is legitimate to suggest that oxide species of the four metal ions are highly dispersed on the support. Cat-7 was the catalyst tested in the oxidation reactions of methane (Figure 2) or ethane (Figure 3), and the results obtain reveal its superiority as compared to the other mono- and bimetallic catalysts examined. The results allocate it the lowest light-off temperature value in the oxidation of methane $\left(\mathrm{T}_{10}=383^{\circ} \mathrm{C}\right)$ and ethane $\left(\mathrm{T}_{10}=355^{\circ} \mathrm{C}\right)$. It is also shown that $90 \%$ conversion of methane or ethane was achievable at 565 or $470^{\circ} \mathrm{C}$, respectively. These results reveal that the recycled Cat-7 is more active than the reported $\mathrm{Co}-\mathrm{Mn}$ (Li et al., 2009) and $\mathrm{Co}-\mathrm{Cr}$ (Chen et al., 2013) catalysts, for a $\mathrm{T}_{90}$ of $320^{\circ} \mathrm{C}$ was determined on the former catalyst, whereas a $\mathrm{T}_{90}$ of $464^{\circ} \mathrm{C}$ was determined on the reported catalyst.

The quatro-metallic constitution of Cat-7 may facilitate the availability on the surface not only of $\mathrm{Cu}$ redox sites $\left(\mathrm{Cu}^{2+} / \mathrm{Cu}^{1+}\right)$, but also of $\mathrm{Fe}\left(\mathrm{Fe}^{3+} / \mathrm{Fe}^{2+}\right)$ and $\mathrm{Ni}\left(\mathrm{Ni}^{3+} / \mathrm{Ni}^{2+}\right)$ (Hussein et al., 1991; Nohman et al., 2005; Hasan et al., 1999). To optimize the oxidation activity of Cat-7 (Table 3 ) these possible redox systems would have somehow cooperated so that the facile reduction of $\mathrm{Cu}^{2+}-$ to- $\mathrm{Cu}^{1+}$ would compensate for the difficult reduction of $\mathrm{Fe}^{3+}$-to- $-\mathrm{Fe}^{2+}$, meanwhile the facile oxidation of $\mathrm{Fe}^{2+}$-to- $\mathrm{Fe}^{3+}$ would compensate for the difficult oxidation of $\mathrm{Ni}^{2+}$-to-Ni ${ }^{3+}$. Hence, Cat-7 assumes a surface exposing more facile electron mobility than the mono-metallic Cat-4 and -5 . It is worth noting, in this regard, that the surface areas of Cat-7, Cat-4 and Cat-5 are similarly close to 105 $\mathrm{m}^{2} / \mathrm{g}$. This may help bringing into prominence the important role of the metallic constitution of the catalyst in determining its total oxidation activity.

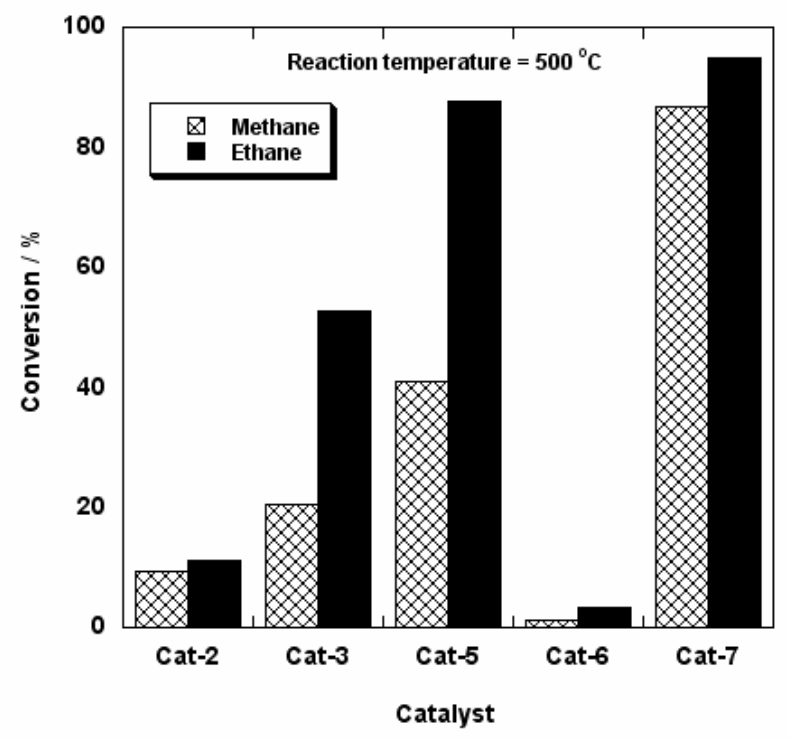

Figure 4. Methane or ethane conversion $(\%)$ at $500^{\circ} \mathrm{C}$ as a function of the catalyst used

Summing up, the results of the catalytic activity measurements indicate that (i) the catalytic combustion of ethane is more facile than methane, (ii) the supported metallic constitution on $\gamma-\mathrm{Al}_{2} \mathrm{O}_{3}$ is the key parameter in optimizing the oxidation activity of the catalysts, (iii) the test catalysts, whether recycled or reference catalysts, can be arranged in the following activity descending order: Cat-7 $>$ Cat-4/-5 $>$ Cat-3 $>$ Cat-1/-2 $>$ Cat-6 (Figure 4), (iv) 
the sole existence (in Cat-4/-5) or co-existence (in Cat-7) of $\mathrm{Cu}$ ions is necessary in the makeup of the active metallic constitution of catalysts, (iv) in the contrary, the sole existence (in Cat-6) and co-existence (in Cat-3/-8/-9) of $\mathrm{Zn}$ ions is a deactivating parameter, and $(\mathbf{v})$ the support $\gamma-\mathrm{Al}_{2} \mathrm{O}_{3}$ phase is instable to the strong acidity $(\mathrm{pH} \leq 4)$ of $\mathrm{Zn}$-containing metal ion impregnating solutions made up using acid-leachates of spent catalysts.

\section{Conclusions}

The results presented and discussed above may help drawing the following conclusions:

1. Inexpensive, $\gamma$-alumina supported transition metal oxide catalysts for the combustion of VOCs, particularly methane or ethane, in air can well be recovered from spent commercial catalysts by mineral acid leaching and subsequent support impregnation, drying and calcination.

2. Cu-containing mono- and multi-metallic catalysts are active in the combustion of methane or ethane in air at $275-600^{\circ} \mathrm{C}$.

3. With a light-off temperature as low as $355-383^{\circ} \mathrm{C}$, and a conversion as high as $90 \%$ at $470-565^{\circ} \mathrm{C}$, a recycled $\gamma$ - $\mathrm{Al}_{2} \mathrm{O}_{3}$-supported quatro-metallic $(\mathrm{Cu}-\mathrm{Ni}-\mathrm{Fe}-\mathrm{Zn})$ catalyst expose surfaces of optimized activity in the combustion of methane or ethane.

4. The catalytic combustion function seems to reside transition metal redox sites (i.e., electronically coupled metal ions of different oxidation states) capable of promoting the necessary electron mobility at the surface.

5. The acidity of the impregnating solutions recovered from spent catalysts must be controlled to $\mathrm{pH}>4$ otherwise the $\gamma-\mathrm{Al}_{2} \mathrm{O}_{3}$ support is transformed into $\gamma-\mathrm{AlO}(\mathrm{OH})$ during the subsequent hydrothermal drying process.

\section{Conflict of interests}

The authors declare that there is no conflict of interests regarding the publication of this paper.

\section{References}

Abdel Basir, S. M., \& Rabah, M. A. (1999). Hydrometallurgical recovery of metal values from brass melting slag. Hydrometallurgy, 53, 31-44. https://doi.org/10.1016/S0304-386X(99)00030-4

Anderson, R. B., Stein, K. C., Feenan, J. J., \& Hofer, L. J. E. (1961). Catalytic oxidation of methane. Ind Eng Chem, 53, 809-812. https://doi.org/10.1021/ie50622a024

Arslan, C., \& Arslan, F. (2002). Recovery of copper, cobalt, and zinc from copper smelter and converter slags. Hydrometallurgy, 67, 1-7. https://doi.org/10.1016/S0304-386X(02)00139-1

Askari, H. M. (2007). Studies of leaching, recovery and recycling of heavy metals. $\mathrm{PhD}$ dissertation, Brunel University, UK.

Aylward, G. H., \& Findlay, T. J. V. (1994). SI Chemical Data (3rd ed.). Australia, John Wiley \& Sons.

Chen, J., Zhang, X., Arandiyan, H., Peng, Y., Chang, H., \& Li, J. (2013). Low temperature complete combustion of methane over cobalt chromium oxides catalysts. Catal Today, 201, 12-18. https://doi.org/10.1016/j.cattod.2012.03.026

Cullis, C. F., \& Willatt, B. M. (1983). Oxidation of methane over supported precious metal catalysts. $J$ Catal, 83, 267-285. https://doi.org/10.1016/0021-9517(83)90054-4

Diehl, F., Barbier, Jr. J., Duprez, D., Guibard, I., \& Mabilon, G. (2010). Catalytic oxidation of heavy hydrocarbons over $\mathrm{Pt} / \mathrm{Al}_{2} \mathrm{O}_{3}$ : Influence of the structure of the molecule on its reactivity. Appl Catal, 95, 217-227. https://doi.org/10.1016/j.apcatb.2009.12.026

Hasan, M. A., Zaki, M. I., Pasupulety, L., \& Kumari, K. (1999). Promotion of the hydrogen peroxide decomposition activity of manganese oxide catalysts. Appl. Catal. A, 181, 171-179. https://doi.org/10.1016/S0926-860X(98)00430-X

Hussein, G. A. M., Sheppard, N., Zaki, M. I., \& Fahim, R. B. (1991). Infrared spectroscopic studies of the reactions of alcohols over group IVB metal oxide catalysts. Part-3: Ethanol over $\mathrm{TiO}_{2}, \mathrm{ZrO}_{2}$ and $\mathrm{HfO}_{2}$ and general conclusions from parts 1 to 3 . JCS Faraday Trans., 87, 2661-2668. https://doi.org/10.1039/FT9918702661

International Center for Diffraction data. (2018). Campus Boulevard, Newton Square, PA, USA.

Jirátová, K., Mikulová, J., Klempa, J., Grygar, T., Bastl, Z., \& Kovanda, F. (2009). Modification of Co-Mn-Al mixed oxide with potassium and its effect on deep oxidation of VOCs. Appl Catal A, 361, 106-116. https://doi.org/10.1016/j.apcata.2009.04.004 
Kamal, M. S., Razzak, S. A., \& Hossain, M. M. (2016). Catalytic oxidation of volatile organic compounds (VOCs) - A review. Atmospheric Environment, 140, 117-134. https://doi.org/10.1016/j.atmosenv.2016.05.031

Kim, D.-C., \& Ihm, S.-K. (2001). Application of spinel-type cobalt chromite as a novel catalyst for combustion of chlorinated organic pollutants. Environ Sci Technol, 35, 222-226. https://doi.org/10.1021/es001098k

Kim, K. J., \& Ahn, H. G. (2009). Complete oxidation of toluene over bimetallic Pt-Au catalysts supported on $\mathrm{ZnO} / \mathrm{Al}_{2} \mathrm{O}_{3}$. Appl Catal, 91, 308-318. https://doi.org/10.1016/j.apcatb.2009.05.037

Kim, S. C. (2002). The catalytic oxidation of aromatic hydrocarbons over supported metal oxide. J Hazard Mater, B91, 285-299. https://doi.org/10.1016/S0304-3894(01)00396-X

Kim, S. C., \& Shim, W. G. (2010). Catalytic combustion of VOCs over a series of manganese oxide catalysts. Appl Catal B, 98, 180-185. https://doi.org/10.1016/j.apcatb.2010.05.027

Kucherov, A. V., Hubbard, C. P., Kucherova, T. N., \& Shelef, M. (1996). Stabilization of the ethane oxidation catalytic activity of Cu-ZSM-5. Appl Catal B, 7, 285-298. https://doi.org/10.1016/0926-3373(95)00046-1

Li, J., Liang, X., Xu, S., \& Hao, J. (2009). Catalytic performance of manganese cobalt oxides on methane combustion at low temperature. Appl Catal B, 90, 307-312. https://doi.org/10.1016/j.apcatb.2009.03.027

Li, L. Y., Ohtsubo, M., Higashi, T., Yamaoka, S., \& Morishita, T. (2007). Leachability of municipal Solid waste ashes in simulated landfill conditions. Waste Management, 27, 932-945. https://doi.org/10.1016/j.wasman.2006.04.014

Liotta, L. F. (2010) Catalytic oxidation of volatile organic compounds on supported noble metals. Appl Catal B, 100, 403-412. https://doi.org/10.1016/j.apcatb.2010.08.023

Morales, M. R., Barbero, B. P., \& Cadús, L. E. (2008). Evaluation and characterization of Mn-Cu mixed oxide catalysts for ethanol total oxidation: influence of copper content. Fuel, 87, 1177-1186. https://doi.org/10.1016/j.fuel.2007.07.015

Mu, Z., Li, J. J., Duan, M. H., Hao, Z. P., \& Qiao, S. Z. (2008). Catalytic combustion of benzene on $\mathrm{Co} / \mathrm{CeO}_{2} / \mathrm{SBA}-15$ and $\mathrm{Co} / \mathrm{SBA}-15$ catalysts. Catal Commun, 9, 1874-1877. https://doi.org/10.1016/j.catcom.2008.03.005

Nohman, A. K. H., Mohamed, M. M., \& Zaki, M. I. (2005). Redox catalysis on manganese oxides: Surface attributes and reaction mechanisms. Current Topics in Catalysis, 4, 43. https://doi.org/10.1002/chin.200638242

Noordally, E., Richmond, J. R., \& Tahir, S. F. (1993). Destruction of volatile organic compounds by catalytic oxidation. Catal Today, 17, 359-366. https://doi.org/10.1016/0920-5861(93)80039-4

Shim, W. G., Lee, J. W., \& Kim, S. C. (2008). Analysis of catalytic oxidation of aromatic hydrocarbons over supported palladium catalyst with different pretreatments based on heterogeneous adsorption properties. Appl Catal B, 84, 133. https://doi.org/10.1016/j.apcatb.2008.03.011

Spivey, J. J. (1987). Complete catalytic oxidation of volatile organics. Ind. Eng. Chem. Res., 26, $2165-2180$. https://doi.org/10.1021/ie00071a001

Spivey, J. J., \& Butt, J. B. (1992). Literature review: Deactivation of catalysts in the oxidation of volatile organic compounds. Catal Today, 11, 465-500. https://doi.org/10.1016/0920-5861(92)80039-P

Standard electrode potential. (2018). Retrieved from https:/en.wikipedia.org/wiki/Standard_electrode_potential

Tahir, S. F., \& Koh, C. A. (1996). Catalytic oxidation for air pollution control. ESPR-Environ Sci Pollut Res, 3, 20-23. https://doi.org/10.1007/BF02986807

Tahir, S. F., \& Koh, C. A. (1997). Catalytic oxidation of ethane over supported metal oxide catalysts. Chemosphere, 34, 1787-1793. https://doi.org/10.1016/S0045-6535(97)00034-9

Todorova, S., Kolev, H., Holgado, J. P., Kadinova, G., Bonev, C. H., Pereniguez, R., \& Caballero. A. (2010). Complete n-hexane oxidation over supported $\mathrm{Mn}-\mathrm{Co}$ catalysts. Appl Catal B, 94, $46-54$. https://doi.org/10.1016/j.apcatb.2009.10.019

Vu, V. H., Belkouch, J., Ould-dris, A., \& Taouk. B. (2008). Catalytic oxidation of volatile organic compounds on manganese and copper oxides supported on titania. AICHE, 54, 1585-1591. https://doi.org/10.1002/aic.11482

Wefers, K., \& Misra, C. (1987). Oxides and hydroxides of aluminum. Alcoa Technical Paper No. 19, Aluminum Company of America. 
Xiao, T.-C., Ji. S.-F., Wang, H.-T., Coleman, K. S., \& Green, M. L. H. (2001). Methane combustion over supported cobalt catalysts. J Mol Catal A., 175, 111-123. https://doi.org/10.1016/S1381-1169(01)00205-9

Zhang, Z., Jiang, Z., \& Shangguan, W. (2016). Low-temperature catalysis for VOCs removal technology and

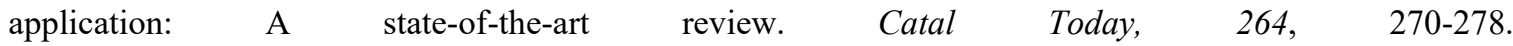
https://doi.org/10.1016/j.cattod.2015.10.040

\section{Copyrights}

Copyright for this article is retained by the author(s), with first publication rights granted to the journal.

This is an open-access article distributed under the terms and conditions of the Creative Commons Attribution license (http://creativecommons.org/licenses/by/4.0/). 